\title{
FOREIGN INVESTORS STRATEGIES IN CEEC ARE IMPROVING: ESTONIA'S CASE
}

\author{
Mart SÕRG\&Jüri SEPP \\ University of Tartu, Estonia
}

\begin{abstract}
In transition economies, where there is a hard need for extensive enterprise restructuring and modernization, the potential benefits of foreign direct investments (FDI) are especially valuable in view of limited domestic resources. Assuming that FDI is beneficial to the host country, the next questions that arise are how and why do foreign investors choose one country over another, what are the motivations behind FDI, and how can a host country retain the investment already there. One purpose of this paper is to look at the motivational factors behind FDI and compare them between different stages of economies. Estonia is an interesting case because it is attracting a considerable amount of FDI. Although a small country, when comparing measures such as FDI per capita and FDI as a percentage of gross domestic products (GDP) with those of other Central and Eastern Europe (CEE) countries, Estonia is one of the top FDI-attracting countries, especially among former Soviet Union states that had to build up an institutional framework from scratch. As a country in transition, Estonia has attempted to create an investment climate favourable for the inflow of foreign investments. Estonia attracts foreign investors with its investor-friendly business climate comprising low risks, low costs, and low taxes. Those investors' assumptions are supported by the country's consistent free market policies that have, firstly, earned Estonia the reputation of having the most liberal trade and investment laws in Europe and, secondly, have boosted the country's international credibility. The largest investors investing in Estonia are our neighbouring countries Sweden, Finland and Germany. The share of the EU Member States was 99\%. Direct investment went mainly to financial intermediation (88\%) but the manufacturing sector is also worth highlighting. The resent trends of FDI indicate that the foreign owners
\end{abstract}

in Estonia are increasing their investments by reinvesting the profit and loan capital in the companies' assets. This tendency demonstrates that foreign investors have succeeded in Estonia and that they have made long-term business plans in this country. Besides, they are making more and more investments through Estonia in the Eastern transition markets, using the experience gained in doing business in the Estonian emerging markets. However, Estonia has much more FDI per GDP than Latvia, Lithuania or Poland. Expectedly, most of the FDI outflow from Estonia goes to the other Baltic States. This expectation is supported by the gravity theory.

\section{INTRODUCTION}

In most countries, FDI serves as one of the engines of successful development. In transition economies, where there is a need for extensive enterprise restructuring and modernization, the potential benefits of FDI are especially valuable in view of limited domestic resources (Demekes et al., 2005). From the point of view of foreign investors most FDI are marketseeking and efficiency-seeking motives. The findings of the United Nations Conference on Trade and Development (UNCTAD, 1999) reveal that FDI continues to increase at a global level as multinational corporations (MNCs) integrate their business operations throughout the world. The report confirms that FDI transfer technology as well as firm specific assets to host countries. Foreign investors from the US, Japan, the EU, and other countries penetrate global markets through FDI. Despite the dominance of market-seeking motives, foreign entities or foreign affiliates turn out to be more export-oriented than local firms. These investors have better access to international production and distribution networks (Makola, 2003).

Assuming that FDI is beneficial to the host country,

This article has been supported by ESF Grants No. 6629, No. 6630 and Target Funding from the Estonian Ministry of Education and Research No. T0107. 
the next questions that arise are how and why do foreign investors choose one country over another, what are the motivations behind FDI, and how can a host country retain the investment already there. One purpose of this paper is to look at the motivational factors behind FDI and compare them between different stages of development of Estonian economy. Estonia is an interesting case because it is attracting a considerable amount of FDI. Although a small country, when comparing measures such as FDI per capita and FDI as a percentage of gross domestic product (GDP) with those of other Central and Eastern European Countries (CEEC), Estonia is one of the top FDI-attracting countries, especially among former Soviet Union states that had to build up an institutional framework from scratch. As a country in transition, Estonia has attempted to create an investment climate favourable for the inflow of foreign investments. During the period from 1992 to 2006, foreign direct investments made up ca $50 \%$ of total foreign investments into Estonia.

Latest developments show that entrepreneurs using Estonia as gateway are rediscovering Eastern markets. It is quite logical as Estonia is an EU border state. This reorientation has also economic reasons. Processing costs and competition level in Eastern European transition countries are lower than in Estonia and the business environment is already relatively stable there. Direct investment outflow of 2006 reached record levels amounting to 12,9 billion kroons (800 mln. $\square$ ) it was equal for $64 \%$ FDI inflow of this year.

In our paper we empirically analyze these tendencies by statistical data and try to find causalities for it. Additionally we bring the case of Hansabank, which have been established subsidiaries in Latvia, Lithuania and Russia.

\section{DIRECT INVESTMENTS INFLOW INTO ESTONIA}

In the difficult period of reforms, the domestic resources are insufficient. Partially due to low income levels coupled with high inflation, the levels of domestic private savings of transition economies are very low then. Because of the lack of resources neither entrepreneurs nor the government can attract the funds the national economy needs. Thus, foreign investment and first of all FDI, can play a very important role in economic recovery, serving not only as an important source of capital, but also as a source of new technology and modern managerial know-how.

After becoming independent in August 1991, Estonia chose an economic model of the transition from command socialism to market economy. Investments are one of the most influential forces that can help a transition economy rise from deep depression, caused by political and economic reforms. Additionally economic problems in the start-up phase have also in the mismanagement before. Estonia with population of less than 1.4 million is the smallest and northernmost of the Baltic States. However, it succeeded in attracting FDI much better than others. Despite the fall of FDI that was forecast to follow the extensive privatization of enterprises, recent years have shown an upward trend.

On the one hand, Estonia attracts foreign investors with its investor-friendly business climate comprising low risks, low costs, and low taxes. Those investors' assumptions are supported by the country's consistent free market policies that have, firstly, earned Estonia the reputation of having the most liberal trade and investment laws in Europe and, secondly, have boosted the country's international credibility. On the other hand, Estonia has been improving its FDI policy in order to maintain its efficiency in the changing market situation in view of Estonia's distinctive feature - its small transitional market. By the amount of FDI per capita, Estonia is the most successful among transition countries (see Figure 1).

\section{FIGURE 1. FDI STOCKS IN CEE COUNTRIES IN 2005}

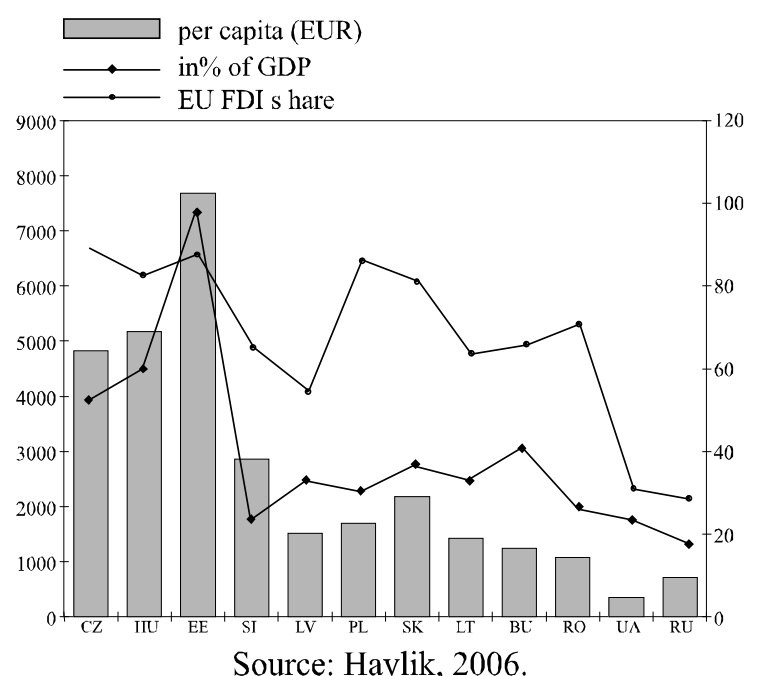

Sachs (1997) lists a set of Conditions to attract and benefit from FDI: low corporate taxes, low tariffs. Good infrastructure, a stable political environment, a competitive labour market and a favourable geography. In Estonia corporate income tax is zero if profits are reinvested, communication infrastructure is modern, political environment is stable; unit labour costs are 
lower than in EU-15 and country has favourable geography to be a trade gateway between East and West. So, Estonia has all conditions to attract foreign investors.

In Estonia FDI are forming approximately half of the total investment inward. When to take into account that during the period 1995-2003 in new EU member states in Czech Republic FDI formed $81,6 \%$ and in Hungary $76,9 \%$, then Estonian FDI position is even better than demonstrated Figure 1 data (Árvai, 2006). Data shows that foreign investment is growing much faster than GDP and at the end of 2005; FDI already formed a sum equal to year's GDP. Estonia's GDP is rapidly growing. In 2005, GDP growth rate was $9,8 \%$, whereas during 2002-2004 the annual growth was approximately $7 \%$. The determinants and effects of FDI have been extensively studied. There are many theories trying to explain why firms start to go abroad (see also Sorrg et al., 2004).

The most general theoretical framework is Dunning's eclectic paradigm, or OLI theory (Dunning, 1973; 1993). It explains why firms decide to start investing abroad, the preconditions (firm specific advantages), where they invest (where the location advantages complementing their ownership-specific advantages are available), and why they select FDI out of many forms of foreign market entry (maximization of their rents). The important aspects of OLI theory are that the location and ownership advantages are necessary, but not sufficient, conditions for FDI. They should be complemented by internationalization, which helps in taking advantage of such conditions.

Wider approach to study FDI therefore includes different aspects of society where later studies using more different international indices as proxies to different aspects of society (Ayalp et al. 2004; Pantelidis and Nikolopoulus, 2006). According to their methodology, there are 31 different factors grouped in 7 main groups to drive FDI - s.c. (salvage charges) and the attractiveness index. According to the results of the study by Ayalp et al. (2004) on the FDI attractiveness index Estonia ranks 8th in this list and are ahead of several EU-15 countries.

The studies by Martinez and Sanchez-Robles (2006) and Carstensen and Toubal (2003) show that FDI is related to democracy and market size. The most complicated matter with regard to this approach is to find reliable indicators a proper proxy to describe a process under study.

To study the motives behind foreign investors we first refer to a study by Glaros (1996), where he focuses on investment coming from the US companies and looks for the advantages and disadvantages of investing in Estonia.

The results indicate that market access is the most important reason of firms came to Estonia, followed by enterprise expansion and trade expansion. The protection of the existing markets and lower costs of production were the two least motivating factors. The biggest advantages of investing in Estonia in the past, according to an open-ended question, were market access, highly educated and skilled workforce, and potential for economic growth. The small market size, excessive bureaucracy, and the possibility of future problems with Russia were the greatest disadvantages. The biggest problems encountered by investors were the scarce availability of finance capital, residency requirements, and the level of government assistance. Labour related factors and market access caused investors the least problems.

Comparing the study by Glaros (1996) with later findings, the shift of motivation towards the efficiency of inputs, especially labour, could be noticed. It has been proved that large differences in relative wage levels increase the potential for production relocation and thus increase FDI (Estrin et al., 2001). Earlier studies do not mention the availability of labour, which is however more often pointed out in later studies.

These studies were mainly carried out on the basis of

TABLE 1. ESTONIAN INVESTMENTS INFLOW (EEK M)

\begin{tabular}{|l|r|r|r|r|r|r|r|}
\hline & 2000 & 2001 & 2002 & 2003 & 2004 & 2005 & 2006 \\
\hline Direct investment & 6,645 & 9,430 & 4,800 & 12,666 & 13,111 & 34,921 & 20,062 \\
\hline Portfolio investment & 1,282 & 1,401 & 5,562 & 7,783 & 13,882 & $-16,370$ & 124 \\
\hline Financial derivatives & - & - & - & 120 & 27 & -111 & 258 \\
\hline Other investment & 2,597 & 3,288 & 6,733 & 6,733 & 13,717 & 30,457 & 40483 \\
\hline Total foreign investment & 10,601 & 14,119 & 17,137 & 27,858 & 38,947 & 48,897 & 60927 \\
\hline Share of direct investment (\%) & 62.7 & 66.8 & 28.0 & 44.8 & 29.8 & 71.0 & 32,8 \\
\hline
\end{tabular}

Source: compiled by the author. 
interviews or questionnaires handed to the managers to describe their incentives for investment decisions. Unfortunately, such method has a few shortcomings, strongly underestimating some macroeconomic parameters, such as privatization, financial infrastructure etc. Estrin, Bevan and Meyer (2001) found in their study a strong causality between privatization and FDI, whereas the method of privatization itself was surprisingly not significant. There was also a strong causality between banking reforms and FDI where banks are serving primarily money transaction and non-equity finance. Therefore, banking crises can be very harmful for FDI. In Estonia, contrary this finding banking crises in 1998 attracted big Scandinavian banks to invest in the Estonian banking sector.

According to the above aspects, attractions for investing in Estonia include the country's geographic location and favourable investment climate. The Estonian government has been making great efforts in the last fifteen years to create an encouraging setting for investors. Apparently, Estonia's success in its FDI policies is not based merely on facilitating foreign investors to enter into the Estonian market, but also on continuously changing the investment climate according to market changes and investors' desires. This helps to enhance foreign investors' wish to extend their business in Estonia in the future and promote investing in Estonia from abroad.

Table 1 shows the decrease in the share of FDI in total foreign investment. The main reason is extremely rapid growth of other investment, including loans. The rapid increase in the share of FDI in 2005 was the result of extraordinary capital movements between the accounts of Hansabank. The changes eflected in a decrease in portfolio investment and an increase in direct investment to theHansabank's share capital. Due to the increase of foreign investors share of Hansabank's capital the participation of foreign investors is now rated as FDI instead of portfolio investment in the Estonian balance of payments.

In 2005, the volume of direct investment in Estonia again reached a record high in the history of compiling the balance of payments. The majority of that accounted for the buying up of shares from minority shareholders by Hansabank's core investor. Consequently, portfolio investment witnessed a 22.7 billion kroons decrease in equity security liabilities.

The largest investors investing into Estonia are our neighbouring countries Sweden and Finland. The share of the EU Member States was 99\%. Direct investment went mainly to financial intermediation $(39,7 \%)$. FDI help enterprises to reconstruct and expand, increasing their volume of production and thus also competitiveness in international markets. Studies have confirmed that FDI plays an important role in the reconstruction of enterprises and supporting economic growth (Djankov, 1999; Ozawa, 1992). Several studies have also shown that foreign-owned companies are more export-oriented than local companies (Rojec, 1998; Lauter and Rehman, 1999).

In small economies like Estonia, relations with foreign countries are very important and it is hard to find a better alternative than open, export-oriented economic policy. Estonia's most important trade partners are the EU countries; their share in the exports of goods amounted to $76 \%$ in 2005 . This requires high competitiveness of domestic producers in order to compete with their foreign competitors. It is also evident that foreign-owned companies are usually more competitive. This is due to the clearly acknowledged need to develop in order to fit into the new market. The balance of payments (BOP) data displays that from 1992 to 2006, i.e. within 14 years, the Estonian exports of goods have increased 21.8 times and that of services 18.1 times.

\section{FOREIGN INVESTMENTS OUTFLOW FROM ESTONIA}

Several studies have shown that foreign investors oriented to developing markets are interested in maximizing the proprietary income (Nunnenkamp, 2000). According to literature, $43 \%$ of German investors in Central and Eastern European countries aim for efficiency and $40 \%$ orient towards new markets (especially in car, cement and chemical industries) (Zschiedrich, 2003:79). Lankes and Venables (1996) and Lankes and Stern (1998) find that the motive of entering new markets dominates in investments into Central and Eastern European (CEE) countries. Naturally, the motive of spreading risks plays a role due to higher economic and financial risks in transition countries compared with developed market economies.

The above-mentioned conclusions are highly expected. The developing markets of CEE countries are indeed riskier and thus offer higher rates of return. In the research of Reininger and Walko (2006) was find that most of the ten new EU member states (NMS-10) had profitability ratios above the euro area average; in all NMS-10 for which data were available, profitability ratios were above the euro area minimum. 
The study of Larimo et al. (1998) concluded that firms of different origin seem to have somewhat different motives for their FDI in Estonia. They divided the countries into three groups, taking into account their investment incentives. The study showed that neighbouring countries like Finland and Sweden are mainly interested in finding a new market, but other countries use Estonia as a gateway for penetrating the markets of the European Union or Russia. Although these data are not recent, they vividly express the strategic motives of investors.

These studies confirm the conclusions of Ozawa (1992) who claims that firms that start losing comparative advantages start to invest abroad. The flying-geese paradigm developed by Kyoshi Kojima (1973) sees that simpler activities will gradually flow out from relatively advanced host countries to newcomer host countries. This theory is relevant in the Baltic Sea region. Data indicates that FDI outflow from Estonia is much more intensive than from our neighbouring post socialist countries. However, Estonia has much more FDI per GDP than Latvia, Lithuania or Poland (see Figure 1), expectedly, most of the FDI outflow from Estonia goes to the other Baltic States. This evidence is supported by the gravity theory. The research of Demekas et al. (2005) also confirms the predominance of gravity factors (host market size and geographical and cultural proximity between the source and host countries) in explaining FDI flows in Central and South-eastern Europe. Our previous research (Sõrg, 2005) already showed that Estonia has gradually lost its cost advantages. The advantages Estonia had 10-15 years ago - high rates of return, very cheap and high-quality labour force, cheap raw materials - have gradually vanished. Due to the EU membership from May 2004, it is inevitable that the convergence of wages, prices and profitability makes these foreign investors' motives less important. On the contrary, Estonian entrepreneurs become more interested in moving on to "better hunting grounds" rather than increasing their investments in Estonia. This calls for thorough research on what should be done in order to boost investing in Estonia in the future. The study of the McKinsey Global Institute referred at the beginning of this paper should be taken seriously. Its final conclusion is that developing countries must continue to build a strong infrastructure, including roads, power supplies, and ports - particularly if they want to attract export-oriented foreign investment (Farrell et al., 2004).

Table 2 data where the structure of FDI inflow and outflow is similar indicate that these companies who invested in Estonia years ago are now apparently moving on to younger markets to earn higher profits. It is easier to move on in the service sector, which is why the latter is prevailing in FDI inflow as well as in outflow. Research of Havrylchuk and Jurzyk (2006) using a dataset comparising 265 banks from 10 CEECs between 19952003 finds that it is profitable for foreign banks to open subsidiaries in transition economies, since in CEECs ROA for foreign banks significantly exceeds that for parent banks in home countries. BOP data clearly demonstrates that the main destinations of Estonian companies are Latvia (23,3\%), Lithuania $(31,0 \%)$ and Russia $(9,4 \%)$.

TABLE 2. ESTONIA'S FDI POSITION BY FIELDS OF ACTIVITY AS AT THE END OF 2006 (\%)

\begin{tabular}{|l|r|r|}
\hline & Inflow & Outflow \\
\hline Financial intermediation & 39.7 & 45.5 \\
\hline $\begin{array}{l}\text { Real estate, renting and } \\
\text { business activities }\end{array}$ & 29.1 & 14.0 \\
\hline $\begin{array}{l}\text { Transport, storage and } \\
\text { communications }\end{array}$ & 9.9 & $\ldots$ \\
\hline $\begin{array}{l}\text { Wholesale and retail } \\
\text { trade; repair }\end{array}$ & 7.8 & 8.0 \\
\hline Manufacturing & $\ldots$ & 14.0 \\
\hline Activities of households & 4.5 & 7.7 \\
\hline Other & 9.0 & 11.6 \\
\hline Total & 100.0 & 100.0 \\
\hline
\end{tabular}

Source: Estonia's International Investment Position ..., 2007; compiled by the author.

The survey conducted between June and September 2001 by the Chair of International Business of the University of Tartu showed that 65 per cent of the Estonian companies investing abroad are indirect investors, i.e. they belong, at last partially, to foreign owners (Varblane et al., 2001). An excellent example of these indirect investments is the case of Hansabank.

Foreign banks just waited for a suitable moment to "run to help" the local banks who have taken too many risks in their business. Foreign banks bought from the stock exchange the relatively cheap shares of the major Estonian banks and in 1998 they were able to acquire a major holding in the share capital of Estonian banks that were facing financial difficulties. So Swedbank became a strategic owner of Hansabank. So, Estonian case supported the finding of Alfaro et al. (2004) that countries with well-developed financial markets gain significantly from FDI. The approach followed by Swedfund, the majority owner of Hansabank Group used a very decentralized "hands off" approach, on the basis of which managers in Estonia are still 
TABLE 3. ESTONIAN FDI STATUS BY MAIN FIELDS OF ACTIVITY AT THE END OF 2005 (EEK BN; EEK 15.6466 = 1 EUR)

\begin{tabular}{|l|r|r|r|r|r|r|}
\hline & \multicolumn{2}{|c|}{ FDI in Estonia } & \multicolumn{4}{|c|}{ FDI from Estonia } \\
\hline & Total & $\%$ & to Russia & $\%$ & to Ukraine & $\%$ \\
\hline Financial intermediation & 54,740 & 47.4 & 2,193 & 56.9 & 574 & 66.0 \\
\hline Wholesale and retail trade; repair & 9,123 & 7.9 & 503 & 13.1 & 38 & 4.4 \\
\hline Transport, storage and communications & 3,464 & 3.0 & 141 & 3.6 & 0 & 0 \\
\hline Real estate, renting and business activities & 18,015 & 15.6 & 96 & 2.5 & 116 & 13.3 \\
\hline Manufacturing & 15,706 & 13.6 & 159 & 4.1 & 98 & 11.3 \\
\hline Other & 14,435 & 12.5 & 764 & 19.8 & 44 & 5.0 \\
\hline Total & 115,483 & 100.0 & 3,856 & 100.0 & 870 & 100.0 \\
\hline
\end{tabular}

Source: Estonian Preliminary Balance of Payments for the Year 2005, 2006; Data of Balance of Payments and Economic Statistics Department of Eesti Pank; compiled by the author.

developing and executing their plans of foreign market expansion.

The internationalization of the Hansabank Group started with small investments in the representative office in Latvia and the establishment of firms providing leasing and life insurance. In June 1996, Hansabank started the next internationalization stage by acquiring $100 \%$ of Deutsche-Lettische Bank in Latvia and its name was changed to Hansabank-Latvija. In July 1998, further expansion of Hansabank occurred inside Estonia by merging with Hoiupank (Savings Bank). As a consequence, Hansabank got a subsidiary in Latvia Zemes Banka, which was merged with Hansabank-Latvia in 1998. In the year 1999, the Hansabanka, subsidiary of Hansabank in Latvia, merged with Ventspils United Baltic Bank (VABB). This deal strengthened the position of the Hansabank Group in Ventspils, one of the most developed regions of Latvia.

In 1997, Estonia's Hansabank made a decision to start operating also in Lithuania and looked for an opportunity of acquisition. In 1998, Hansabank was not able to find a bank suitable for acquisition, and therefore, the bank decided to conduct a Greenfield investment. Hansabankas in Lithuania started its activities from scratch in Vilnius City in July 1999, and later on expanded to other towns. Hansabankas was the first foreign subsidiary bank in Lithuania. After 18 months of operations, the bank's assets grew to EUR 95 million, gross loans to EUR 36 million and client deposits to EUR 67 million. Thus, the bank ranked fifth in terms of client deposits out of the thirteen commercial banks in Lithuania as at the end of 2000. But this organic growth of Greenfield banks was unsatisfactory for Hansabank and acquisition was again top priority in Lithuania. The year 2001 marked the start of rapid expansion on the Lithuanian banking market. In addition to strong organic growth, the Hansabank Group also completed the acquisition of the largest retail bank in Lithuania, Lietuvos Taupomasis Bankas (LTB) in April 2001. The privatization process of LTB was long and complicated. The Hansabank Group expressed their interest in purchasing LTB during the entire long privatization process.

Now Hansabank already reached the Russian banking market. In 2005 Hansabank opened a subsidiary in Moskow, from March 2006 they started in SanktPetersburg and from August 2006 in Kaliningrad. In Sweden Swedbank group has more than 470 branches. In The Baltic countries Swedbank group has via Hansabank already 280 branches

(http://www.hansabank.ru).

Thus, the case of Hansbpank proved that the theory of internationalization is true for both inward and outward FDI of Estonia. But so Hansabank's strategy do not support the conclusion of Ledyaeva and Linden (2006) that investment risks are so high in Russia that only high profits in export oriented extractive industries (e. g. fuel industry) have attracted foreign investors.

Russia and Ukraine are big and challenging markets for every businessman. According to 9th Annual Global CEO Survey (2006) of Pricewaterhouse Coopers, 54\% of global CEOs are planning to open offices in China, followed by Russia (48\%), India (44\%) and Brazil $(35 \%)$. It is quite expected that Estonian companies also seek to invest in Russia. Ukraine also started to interest Estonian businessmen after democracy was restored there, but Russia was still preferred. Estonia has a common border with Russia and is highly dependent on the Russian market (transit services and imports of fuel products). But Ukraine is also a very large and attractive market. Data shows that direct 
investments in both countries have been rapidly growing in the last five years. In 2005, there was a sudden increase in FDI flows from Estonia to Russia and Ukraine. Thus, there exist reasons to study the influence Estonia's accession to the EU on 1 May 2004 had on FDI.

The data of Table 3 show that the structure of FDI by fields of activity from Estonia to Russia and Ukraine is similar to the structure of FDI inflows to Estonia. The financial intermediation sector is leading in both countries. However the share of foreign ownership in Estonian banking sector is near $100 \%$. We may conclude that foreign owners are using Estonian experiences to go ahead to the Eastern risky markets.

To the end of 2006 FDI from Estonia to Russia formed 3,98 bn. EEK and from Russia to Estonia even 4,38 bn. EEK. During last two years Estonians have invested to Russia 2,1 bn. EEK. It is a bit more than during previous eight years (Äripäev, 2007). The main reason for the modest share of Estonian FDI to Russia and Ukraine is that business environment in these countries is not very favourable yet. If the environment improves, investments will also start to grow. For example, Uiboupin found in his research (2006) that the foreign ownership in the Ukrainian banking sector is currently comparatively low, because the market was opened to foreign capital only in July 2005. At the end of 2005, there were nine foreign banks operating in Ukraine, but their market share in total assets was only $7.4 \%$ because of the restrictions on private lending. Many foreign banks were expected to invest in the Ukrainian banking sector already in 2006.

From the perspective of foreign investors, country risk may be defined as the series of national and international events that affect the value of real and financial assets as well as companies' operations and foreign investments (Duran and Lamothe, 2004). Our survey showed that country risk is also a key issue for investment development between Estonia, Russia and Ukraine. Decreasing the county risk will enable to fully use the potential of these relations for both sides.

\section{CONCLUSIONS}

The objectives of the present paper were to point out the main aspects of Estonia's success in attracting a significant amount of FDI, and to forecast the country's prospects for attracting further FDI. On the one hand, Estonia attracts foreign investors with its investorfriendly business climate comprising low risks, low costs, and low taxes. Those investors' assumptions are supported by the country's consistent free market policies that have, firstly, earned Estonia the reputation of having the most liberal trade and investment laws in Europe and, secondly, have boosted the country's international credibility. On the other hand, Estonia has been improving its FDI policy in order to maintain its efficiency in the changing market situation in view of Estonia's distinctive feature - its small transitional market.

The resent trends of FDI indicate that the foreign owners in Estonia are increasing their investments by reinvesting ca $60 \%$ of profit and loan capital in the companies' assets. This tendency demonstrates that foreign investors have succeeded in Estonia and that they have made long-term business plans in this country. Besides, they are making more and more investments through Estonia in the Eastern transition markets, using the experience gained in doing business in the Estonian emerging market.

It indicates, that the advantages Estonia had 10-15 years ago - high rates of return, very cheap and highquality labour force, cheap raw materials - have gradually vanished. Due to the EU membership from May 2004, it is inevitable that the convergence of wages, prices and profitability makes these foreign investors' motives less important. On the contrary, Estonian entrepreneurs become more interested in moving on to "better hunting grounds" rather than increasing their investments in Estonia.

Asia has became a key part of the global economy, boasting three of the ten largest economies (China, Japan and India) and accounting for more than 35 percent of world GDP. Asia has also integrated into global capital markets, capturing about 40 percent of net private capital flows going emerging markets. Two-thirds of private equity flowing into Asia is in the form of direct investment (Asia's Role ..., 2006). In some experts view the future role of the Estonian economy seems to be some kind of a service centre for other eastern European countries trying to integrate into the world economy. With their specific knowledge of those markets and the experience how to overcome problems in the transition process Estonia may play a similar role to these countries like Hong Kong played for China. 


\section{REFERENCES}

9th Annual Global CEO Survey. Globalisation and Complexity (2006). Pricewaterhouce Coopers.

Alfaro, L. et al. (2004) FDI and economic growth: the role of local financial markets. In: Journal of International Economics, 64, pp. 89-112.

Äripäev, 2. mai 2007.

Árvai, Z. (2006). New EU member provide lessons in opening up capital accounts. In: IMF Survey, February 20, Vol 35, No 4, pp. 56-57.

Asia's Role in the World Economy (2006). In: Finance and Development. International Montary Fund. June, pp. 14-15.

Ayalp, T. et al. (2004). FDI Attractiveness of Turkey: A Comparative Analysis. The Turkish Industrialists and Businessmen's Association and the Foreign Investors Associations of Turkey, Feb 2004.

Carstensen, K and F. Toubal (2003). Foreign Direct Investment in Central and eastern European Countries: A Dynamic Panel Analysis. Journal of Comparative Economies, Vol. 32, pp. 3-22.

Comments on Estonia's Preliminary Balance of Payments for 2006 (2007).

http://www.bankofestonia.info

Demekas, D. G. et al. (2005). Foreign Direct Investment in Southeastern Europe: How (and How Much) Can Policies Help?.IMF Working paper, WP/05/110.

Djankov, S. (1999). Ownership Structure and Enterprise Restructuring in Six Newly Independent States.

Comparative Economic Studies, Vol. 41, Issue 1, pp. 75-96.

Dunning, J. H. (1973). The determinants of international production. Oxford Economic papers, 25.

Dunning, J. H. (1993). Multinational Enterprises and the Global Economy, Wokinghann: Addison-Wesley Publishers.

Duran, J. J. and P. Lamothe (2004). The Country Risk Premium. What is contained within the Political Risk and Sovereign Risk indexes? European Research on Foreign Direct Investment and International Human Resource Management. Vaasan Yliopiston Julkaisuja.
Selvityksiä ja raportteja 112. Vaasa, 2004, 1k. 84-98.

Estonia's International Investment Position and Gross External Debt as at 31 Detsember 2006 (2007) http://www.bankofestonia.info

Estonian Preliminary Balance of Payments for the Year 2005 (2006). Eesti Pank.

Estrin, S., Bevan, A., Meyer, K. (2001). Institution Building and the Integration of Eastern Europe in International Production. ECB Working Paper 16/01.

Farrell, D., J. K. Remes and H. Schults (2004). The truth about foreign direct investment in emerging markets. The McKinsey Quarterly 2004, Number 1, pp. 25-35.

Glaros, C. (1996). American Investment Survey. Mimeo. Estonian Investment Agency, July 1996.

Havlik, P. (2006).Economic Situation, Competitiveness and Outlook for the New EU Members (2006).PWEI Conference slides, Turku, September 2006.

Havrylchyk, O. and E. Jurzyk (2006). Profitability of foreign banks in Central and Eastern Europe: Does the entry mode matter? Bank of Finland, BOFIT Discussion Papers No. 5.

Kojima, K. (1973). A macroeconomic approach to foreign direct investment. Hitotsubushi Journal of Economics, 14(1), pp. 1-12.

Lankes, H.-P. and A. J. Venables (1996). Foreign Direct Investments in Economic Transition: The Changing Pattern of Investments. Economies of Transition, Vol. 4, No. 2, pp. 331-347.

Lankes, H.-P. and N. Stern (1998). Capital Flows to Eastern Europe and the Former Soviet Union. EBRD Working Paper, No. 27.

Larimo, J., Miljan, M., Sepp, J., Sõrg, M. (1998). Foreign Direct Investments in Estonia. HWWA- Report 172, Hamburg.

Lauter, G. P. and S. S. Rehman (1999). Central and East European trade orientation anmd FDI flows: preparation for EU memberships. International Trade Journal, Vol. 13, Issue 1, pp. 35-52.

Ledyaeva, S. and M. Linden (2006). Foreign direct investment and economic growth: Empirical evidence from Russian regions. In: BOFIT Discussion papers, 
17. Bank of Finland.

Makola, M. (2003). The Attraction of the FDI by the African Countries. Biennial ESSA Conference: Sommerset West: Cape Town, Sept 2003.

Martinez, V., Sanches-Robles, B. (2006). FDI, Democracy and Growth in Central and Eastern Europe and the Former Soviet Union: 1990-2003. IAES Conference, Berlin, April 2006.

Nunnenkamp, P. (2000). Ausländische Direktinvestitionen und gesamt-wirtschaftlihes wachstum in Entwicklungs- und Schwellen ländern. Die Weltwirtschaft 2/2000, Kiel.

Ozawa, T. (1992). Foreign Direct Investment and Economic Development. Transnational Corporations, Vol. 1, no. 1, pp. 27-54.

Pantelidis, P, Nikolopoulus, E. (2006). FDI Attractiveness in Greece. IAES Conference, Berlin, April 2006.

Reiniger, T. and Z. Walko (2006). The Financial Situation and Financing of Nonfinancial Corporations in the Ten New EU Member States - A First Empirical Orientation. In: Focus on European Economic Integration No 2/06. Oesterreichische Nationalbank, pp. 134-151.

Rojec, M. (1998) Restructuring and Efficiency upgrading with foreign direct investment. Phare-ACE Research Project "Impact of foreign direct investment on efficiency and growth in CEEC manufacturing. No. P96-6183, 26 p.

Sachs, J. D. (1997). Ireland's Growth Strategy: Lessons for Economic Development. In: A. W. Gray (ed.) International Perspectives on the Irish Economy. Indecon, Dublin.

Sõrg, M. (2005). Foreign Investors Strategies in Estonia. - Business Development Possibilities in the New European Area. Vilnius University, Faculty of Economics, Business Department. Scientific proceedings. Part I, 1k. 242-247.

Sõrg, M., Uiboupin, J., Varblane, U., Vensel, V. (2004). The internationalization of Estonian banks. Inward versus outward penetration. - Financial Markets in Central and Eastern Europe. Stability and efficiency perspectives. Ed. By M. Balling, F. Lierman and A. Mullineux. Routledge Studies in European Economy.
Routledge: Taylor \& Francis Group, pp. 251-290.

Uiboupin, J. (2006). Opening-up to Foreign Banks in a Transition Economy: A case of Ukraine. 14th Scientific Conference on economic Policy. TartuVärska, 2006. Berliner Wissenchafts Verlag GmbH and Mattimar.

UNCTAD (1999) United Nations Conference on Trade and Development. New York and Geneva. United Nations.

Varblane, U. et al. (2001).Estonian Outward Foreign Direct Investments. Univesity of Tartu. Faculty of Economics and Business Administration. Working Paper No. 9.

Zschiedrich, H. (2003). Foreign Direct Investments (FDI) in the Transition Progress - Motivation, Forms and Effects of FDI in Selected Central Eastern European Countries (CEECs). [In:] Proceedings of the 11th Annual Cinference on Marketing and Business Strategies for Central \& Eastern Europe, December 4-6, 2003. Ed. by Petr Chadraba and Reiner Springer. Vienna, pp. 75-86. 